\title{
Editors:
}

Jaime Almansa Sánchez \& Elena Papagiannopoulou

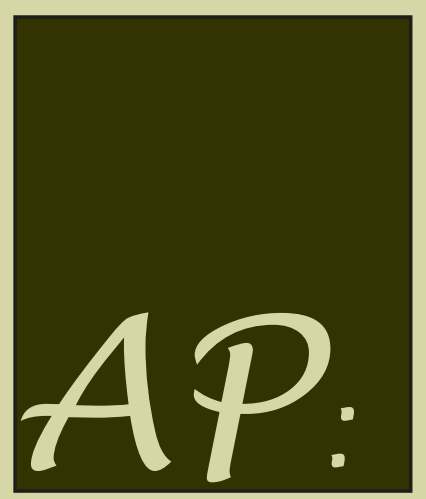

www.arqueologiapublica.es

Ontine Journat in Public Archaeology 


\title{
REVIEWS
}

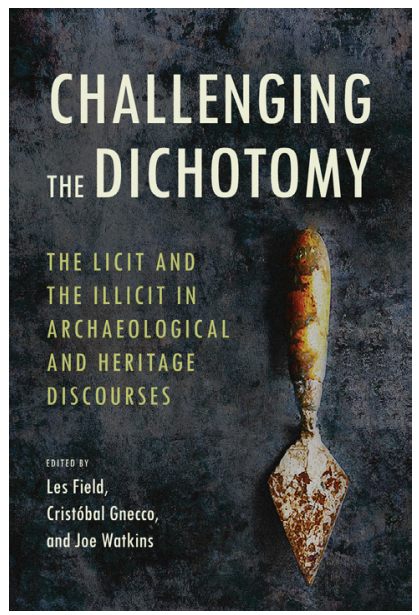

Ignacio RODRÍGUEZ TEMIÑO

Challenging the dichotomy. The licit and the illicit in archaeological and heritage discourses

\author{
[Ed. by Les Field, Cristobal Gnecco \\ and Joe Watkins] \\ University of Arizona Press \\ ISBN: 9780816531301 \\ 216 pages
}

\section{Postmodern archaeology with a dash of magic realism}

Challenging the Dichotomy: The Licit and the Illicit in Archaeological and Heritage Discourses (hereinafter, Challenging the Dichotomy) gathers the talks from a workshop entitled "Illicit Excavation, Archaeology, Communities and Museums: An International Workshop on Complex Relationships and Future Perspectives", held in Bogotá and Villa de Leiva (Colombia) in 2011 and funded by the Wenner-Gren Foundation.

As indicated by the book's title, the editors consider the included works to be united by a common desire to question the dichotomy between the licit and the illicit. They further consider this dualism to be the product of the establishment of the modern order. This order is characterised by the link between the academic development of archaeology as a discipline and the legal system governing the objects and artefacts that fall within its scope of interest, i.e. "archaeological heritage". This organisational approach leaves ancestral practices lacking academic support outside the legal order, rendering them "illicit". 
In response to this exclusion, the editors note that some of the outlawed actions related to archaeological objects and the past reflect forms of logic and connections other than those hegemonically imposed by modernity. They further argue that such practices should not be labelled illicit, but rather should be recognised as subject to a different legitimacy/legality.

In countries of colonial origin, such as the majority of those analysed in Challenging the Dichotomy, this situation has resulted in a conflictive dichotomy of legalities with their corresponding legitimacies. In linking archaeology and archaeological heritage, modernity has created a legitimacy that determines a portion of what is legal. However, the indigenous societies that predated the arrival of Europeans benefit de facto from a legitimacy based on their ancestral rites, on a communion with their roots. This legitimacy empowers them to dictate their own legality, different from that of the West. Given the existence of this dual legitimacy/ legality, the descendants of the colonised are just as entitled as the descendants of the colonisers to consider academically sanctioned practices illicit.

In their introduction, the editors warn of the harmful impact archaeology has had on the dichotomy between modern and premodern legitimacies. The discipline has made objects the core of its research, thereby contributing to reify the past. Ethnology, in contrast, places the emphasis on people, on their ancestral rights and folk culture. This revitalises the past by incorporating it into the present. The editors also turn to ethnology to deconstruct modern heritage discourse, which is based on the classic actions of stewardship, protection, conservation and dissemination (or communication). Ethnology makes it possible to identify who benefits from historical heritage narratives, in what is (self-) described as "critical [cultural] heritage studies".

The book consists of twelve chapters, each by a different author or authors. The editors have divided them into two broad parts. The thrust of Part 1 is to expose the complex relationships between nation states and the institutionalisation of archaeological truth, which is a product of the aforementioned tie between the discipline and law. In this part, Nick Shepherd examines the state of play in South Africa, during apartheid and in the recent post-apartheid 
era, through specific cases centred on the historical and presentday treatment of the human skeletal remains of the aboriginal populations. In his chapter on guaquería in Colombia, Wilhelm Londoño contrasts reality and the law. Lena Mortensen describes this same conflict in Honduras. In that country, archaeological objects are in the public domain, regardless of whether they are currently held in private collections, yet this does not prevent them from being commodified. She presents the case of the Copán site by way of example. Joe Watkins focuses his analysis in the US, on the relationship between the Indian nations and state and federal law on archaeological heritage. Ioanna Antoniadou turns her gaze to Greece. She argues that the condemnations of looting issued by the professional archaeological establishment in that country are problematic because they marginalise narratives other than those deemed appropriate during the constitution of the nation state. Part 1 concludes with a chapter by Khaldun Bshara that seeks to expose the utter disregard shown by both Israeli and Palestinian authorities for popular architecture in the occupied territories of the West Bank.

The chapters in Part 2 examine specific cases in which this dichotomy of legitimacies comes into play. Julie Hollowell analyses the origin, causes and consequences of the excavation of small walrus ivory sculptures by native Eskimos in the Bering Strait, on both St Lawrence Island and the American and Russian shores. Her analysis places special emphasis on the roles played by traders, collectors, researchers and public authorities. Cristóbal Gnecco and Juan Carlos Piñacué discuss the division between the licit and illicit at the Tierradentro Archaeological Park (Colombia). They describe how it pits the popular rites of local residents with regard to the guacas against the guidelines of the Instituto Colombiano de Antropología e Historia (Colombian Institute of Anthropology and History or ICANH), the government body responsible for their conservation. Alejandro Haber focuses on the same dichotomy between indigenous populations and public authorities in Catamarca (Argentina). Les Field uses the Colombian Museos del Oro (Gold Museums), especially the one in Bogotá, to examine the co-existence of guaquería and archaeology, a co-existence that challenges the division between the licit and illicit. He also compares the reifying effect of archaeology on gold objects with wampum, 
the shells used by North American Indians to make adornments. Unlike, gold, wampum is regarded as an historical object. Finally, Paul Tapsell analyses the evolution of the integration of traditional Maori rationalities into the law and management of cultural artefacts in New Zealand.

As this brief summary shows, Challenging the Dichotomy fits perfectly within the framework of postcolonial archaeology. The defence of indigenous legitimacies, or those of other historically alienated minorities, is indisputably an essential enterprise for archaeology. The field thus joins other social and humanistic disciplines in denouncing the perpetuation of intellectually colonial situations.

Archaeology has joined this trend in terms of theoretical development (Hawley 2015) and through the implementation of practices affecting both the research of historical periods and, especially, how we understand and manage archaeological heritage (Lydon and Rizvi 2012). It is a deconstructive process à la Derrida to break the Western hegemony over the indigenous reality and its past.

An in-depth discussion of postcolonial archaeology lies beyond the scope of this review. Suffice it to say that, personally, I consider legitimate the call to decolonise the discipline, to return artefacts held by museums and other institutions acquired by Western powers during the colonial era. It is a call for an ethical commitment to respect ethnic minorities and, thus, the breadth and legitimacy of views on the meaning of the archaeological record that differ from those traditionally considered academic.

Challenging the Dichotomy offers examples of this dichotomy between the licit and the illicit from almost every continent. However, it pays most attention to a specific form of relationship with the past, typical of the lands of the Tahuantinsuyo, namely, guacas (or huacas, depending on the country). This relationship's illegal status under modern law bears clear witness to the conflict of legitimacies the book sets out to explore.

The word guaca (or huaca) comes from a complex concept, related in extenso to the sacred, that is present in both of the main Andean languages: Quechua and Aymara. The modern 
transliteration would be waqa or wak'a, respectively. Following a process of semantic bleaching, which will be discussed below, today the term guaca is understood to refer to non-archaeological excavations of pre-colonial funerary structures or places of worship for the purpose of extracting any movable property they might contain for collection or sale. A guaquero or huaquero is someone who engages in this practice. In the Andean world, most guaqueros are indigenous (Yates 2013). In this regard, it is different from Europe, where detectorists travel to rural areas to conduct their searches.

Challenging the Dichotomy offers a very convincing narrative on guacas. However, underlying the sweeping rhetoric are problems of several orders that incline me to disagree with the book's stance. I am concerned by its possible alignment with a certain current that tends to downplay the impact of looting (Hollowell-Zimmer 2003; Proulx 2013; Thomas 2016). Advocates of this view tend to identify looting exclusively with the aim of supplying the international black market. They thus often ignore so-called "low-end looting". This latter type of looting is defined as undocumented excavations in which the finds are sent not straight to the international art or antiquities market, but rather to less lucrative and often less visible markets or sometimes to no market at all. It would include metal-detectorists. In the US, there has been a shift away from condemning collectors of archaeological artefacts and warning of the irreparable harm they do (Mallouf 1996; Barber 2005). Instead, they are increasingly defended and their motives are examined and rationalised as "social practices" that provide individuals with "ontological security" (Hart and Chilton 2015). In this view, looters and collectors are alienated minorities, victimised by the preponderant position of professional archaeology and its ethical imperatives.

Challenging the Dichotomy takes no position on whether the decolonisation of colonial archaeological research through the practice of traditional forms of relating to the past, such as guaquería, should be allowed to exhaust a country's cultural resources for the sake of international collecting. This lack of red lines feeds back into the logic of "low-end looting". Whilst the editors distance themselves from actions of severe looting in their introduction, I am afraid that that formality is not enough. 
Despite what the editors claim in the introduction to Challenging the Dichotomy concerning the authors' unity of thought with regard to the central idea of the workshop that gave rise to the book, the content of the chapters is not so unanimous. They could have chosen to divide them up differently, separating those authors who propose overcoming the current dichotomous situation, usually through the recognition and integration of a certain degree of autonomous management of archaeological artefacts by native communities, from those who seem content to demand indigenous legitimacy.

In this regard, Hollowell presents a paradigmatic case. In her chapter, she very clearly shows how protective state intervention on the integrated coast of the former USSR has enabled the conservation and knowledge of the history of the native populations living in the Bering Strait. This stands in contrast with the systematic looting conducted by the Eskimos residing on the Alaskan coast and the island of St. Lawrence, which is driven by commercial interests and collectors.

\section{$* * *$}

One aspect of Challenging the Dichotomy that drew my attention was precisely the lack of a clear distinction between things that, in my view, are not comparable. This reminded me of magic realism, the well-known literary device that seeks to eliminate the red lines that separate reality from the extraordinary. One of its primary practitioners, Gabriel García Márquez, claimed he sought inspiration for the novels he set in Macondo in the stories his grandmother had told him, which seamlessly intermingled real and fantastical characters.

In this book, the arguments used to support positions are often drawn from the experiences of the authors themselves (Haber's case) or from ethnographic interviews (Antoniadou's case). There is nothing wrong with this approach except, in my view, the ease with which anecdote can be mistaken for category. A deeper analysis of the data is lacking, a Geertzian "thick description" (Geertz 1998) that goes beyond mere opinions or the superficiality of supposedly ancestral customs. 
I mention these authors by way of example, but this recourse to magic realism can be found in others as well (Gnecco, Piñacué, Watkins or Shepherd), when they mix data sources of highly unequal reliability in a single text without a moment's hesitation. I understand that they are seeking to provide an account of the past and of heritage practices reached by consensus with the native populations to whom they lend their voice. However, I believe much stands to be lost in such trade-offs, through concessions on aspects that are crucial to understanding what happened or is happening, why, and why we want to know about it now.

This does not strike me as a trivial matter. Voltaire argued that it was necessary to replace the memorialist chronicle with rationality to ensure that history provided a plausible account of the past (Arouet [Voltaire] 1765). True, the French philosopher was speaking of the truth, but as that concept triggers no small reservations in me, I have taken the liberty of referring to plausibility instead. Perhaps the participatory aspect should lie not so much in defining the data or the means used to learn what happened or is happening as in how we return to it and use it in the present.

The need to rid ourselves of the arrogance of professional historians, their refusal to relinquish their monopoly on the truth, cannot be left to the chance of any conception of the past. On the contrary, methods exist (and are used) to strip the experts of that monopoly, taking into account the opinion of the citizenry (indigenous or otherwise). This is what is known as "cultures of anyone" and collaborative knowledge, which generate states of opinion capable of setting the agenda of both the experts themselves and the public authorities (Moser et al. 2002, Moreno-Caballud 2017). To achieve this, one need not transgress the limits imposed by the common interest. This form of subversion of the monopoly of experts is also related to the models of scientific creation and communication (Lewenstein 2003).

In Antoniadou's chapter, one of the people interviewed, a practitioner of illegal digs, questions his methods when he briefly comes into contact with an academic research project. This fact made me reflect on the equality of legitimacies the author establishes between the two practices. Non-academic practice seems to be built on ignorance of the methods and purposes of 
academic practice. Ignorance is a very tenuous red line; when it is crossed, it gives rise to an ethical reconsideration of the earlier illegal digs. This same experience is common amongst metal detectorists in Spain (Rodríguez Temiño and Matas Adamuz 2012). When the comparison of two positions reveals that one has such an exceedingly fragile glass ceiling, it is only through the use of magic realism that they can both be assigned the same epistemological and ethical status.

The Greek cases presented by Antoniadou include an underlying issue of education that the author does not address. I am not referring to an elitist interpretation of education in the sense of access to university studies and, thus, to the right to unearth the past and own its remains. That issue too often involves a line of thought I find to be deeply neo-conservative (Cuno 2008, English 2013). Rather, I am referring to the processes of co-generation of knowledge. I know this is a thorny issue for postmodern criticism, as it hides content that could easily be labelled classist. However, posing the question in terms of the right to access the material remains of the past does not help to solve it. In my view, the key lies in the purpose of the intervention and its impact on the common interest (Rodríguez Temiño 2016).

\section{$* * *$}

I believe that the dichotomy expressed in Challenging the Dichotomy, between the licit and the illicit, is best understood from philosophical perspectives that are not explicitly addressed in the book. It is not my intention to artificially enrich this review with scholarly quotations or sociological studies on postmodernity. Rather, I hope to shed light on the central theme of Challenging the Dichotomy, as a better understanding of the phenomenon will allow us to look for solutions. That is in no way trivial. The very lack of possible ways of overcoming the dichotomies exposed in some of the chapters of Challenging the Dichotomy exudes a disturbing sense of resistance to change. It is as though some of the authors delight in merely exposing the conflict, barring the way to any possible resolution.

Even when episodes that empower indigenous peoples to a certain extent are deemed acceptable in Challenging the Dichotomy, 
these paths are not explored. Nor are scenarios proposed to facilitate understanding between the opposing positions. As we will see, that is one of the main risks of postmodernism: its latent neo-conservatism, an intransigency that positions it as a mere intellectual fad that ultimately serves to justify the prolongation of unjust situations.

In the field of archaeological theory, the adjective "postmodern" tends to be equated with that of "post-procedural". However, in this case, I prefer to keep the term "postmodern", as it better reflects the assumption of some of the currents of thought that underpin the so-called "postmodern condition" (Lyotard 1989).

Postmodern philosophy has given a place of honour in its line of argument to explaining the markedly discontinuous way in which the use of the prefix "post-" with the term "modernity" should be understood. Although it has established itself as a contemporary fad, especially in the world of art and architecture, postmodern thought is not a form of snobbery. It is a sensibility that has been present in Western society since the end of the last century that seeks to rehabilitate the subject, rescuing it from the state of deferral in which the rise of reason had left it. Today, its advocates include philosophers, sociologists, and other intellectuals who, above and beyond their (more or less prêt a porter) adherence to certain currents of thought, are characterised by their use of instruments left by Nietzsche, Heidegger, Benjamin or Wittgenstein, amongst others, to deconstruct the edifice of modernity. Postmodern thought is not unique, nor is it set in stone; it changes and evolves, although certain constants remain.

Here, I am interested in three aspects of postmodern thought for their ability to explain what I consider to be the tacit keys underpinning the dichotomous vision espoused in some chapters of Challenging the Dichotomy. The first is the decline of modern metanarratives and the prominence of "language games" as an explanation of the various opposing positions. The second is the preterition of history in the postmodern narrative, in this case, combined with a kind of disciplinary struggle between history and ethnology. Finally, the third is the radical anti-modernity deployed in certain chapters, which likewise encompasses the institutions emanating from the state. 
I believe that the conflict described in Challenging the Dichotomy between the competing conceptions of archaeological heritage, whether guacas or human skeletons, held by native peoples and academic archaeologists or anthropologists can be likened to the postmodern concept of "language games". Such a comparison makes it possible to understand not only the nature of each position, but also its consequences. For Jean-François Lyotard (1989), the fall of modern metanarratives has led to the emergence in present-day society of myriad "language games", whose flexibility enables better adaptation to each situation or interest group. Obviously, guaquería in Andean populations (and Latin America in general) did not emerge as a result of the abandonment of universal metanarratives. Nevertheless, this abandonment did influence the importance given to those vernacular modes in academic discourse. We will return to the role of these intellectuals below.

These "language games" consist of statements whose legitimacy stems from rules agreed by the players of the game itself, without any reference to a higher moral order. In this scenario, all "language games" are equally valid and are comparable because they have the same legitimacy. This would include the "language game" used by indigenous peoples and the intellectuals who represent them in academia through their defence of a centuriesold practice. It would also include the "language game" used by archaeologists in their demand for expert treatment of the remains of the past as a tolerable formula for managing them. Therefore, both are recognised as having the same interpretative capacity in their respective spheres. As Londoño writes in his chapter, the two worlds mutually ignore each other. This equality of conditions circumvents any hierarchical ordering between them. Justice is limited to preventing the delegitimisation of either of the parties to the différend (difference, in the sense of a dispute). Lyotard considered the imposition of points of view by those in positions of power to be "terrorist behaviour"; hence, the constant demands for the recognition of other legitimacies found throughout Challenging the Dichotomy.

However, the free competition of Lyotardian "language games" is somewhat naïve and dangerous. If the rational ability to reach a consensus, which, as noted, is largely unaddressed by some of 
the authors in Challenging the Dichotomy, is left unexplored, what emerges first is a highly cynical pragmatism that considers the hegemonic option to be a central category in the political order, with the consequent exclusion of the non-dominant alternative. From this perspective, social objectivity is established through acts of power (Laclau 1996). The case presented by Khaldun Bshara about events in the Israeli-occupied territories in the West Bank is a clear example of this logic.

The recognition of indigenous legitimacy as an impregnable fortress, with no exploration of the option of consensus, leads to an aporia. If there is no possibility of reaching shared ideas about the meaning of truth, justice, ethical discernment or rational preferability, what possibility is there of escaping the barbarism or violence of the more daring faction? The extreme autonomy of the participants in different "language games" ends up placing those guided by whim and those guided by rational criteria on an equal footing (Mardones 1990). The only solution postmodern thought seems to offer in the case of conflict is perplexity yet not the tools to remedy or alleviate it.

The second aspect of the postmodern influence I detected in Challenging the Dichotomy is a blatant distrust, in some of the authors, of archaeology as a historical discipline. This ethnological (sometimes even ethnographical) bias against archaeology sprinkled throughout the book reduces the discipline of archaeology to the search for and recovery of objects, which has not been true for decades. Today not only is archaeology a branch of knowledge that has benefited from extensive theoretical and practical developments in the field, it also has a multifaceted relationship with the public and its practitioners care about the ethics of their behaviour visà-vis the rest of the population (Scarre and Scarre 2006). Many of these dichotomies between archaeology and ethnology are fuelled by the third characteristic I will discuss below, an anti-modernity that manifests as a mistrust of one of the main achievements of modernity, namely, government bodies.

Dichotomies such as those proposed by Shepherd in his chapter on the events that took place on Prestwich Street in Cape Town during the preliminary excavations for the construction of a shopping complex strike me as highly contrived interpretations. In 
any case, they might reflect a practice of urgent urban excavations influenced by a wide range of situations, regardless of discipline and of the identity of the practitioners. There are countless cases of professional archaeologists who have fuelled social movements for the conservation of remains that the government had initially written off.

Piñacué, Gnecco, Field, Watkins and Haber advocate the internal logic of guaquería, stressing that it reflects a system of indigenous values of a symbolic nature involving magical-religious dimensions and socially instituted rituals. As I am not a specialist in Andean archaeology or history, I cannot argue with that view, which I accept as valid. However, I do find lacking historiographical references on the origins of this practice and how it has evolved over time. Only Field addresses these points, and only quite cursorily. The other authors refer to its contemporary practice, which they link to a customary practice, seemingly without any problems. It would seem that little or nothing has changed in hundreds of years. That may be true, but there are certainly other researchers, primarily historians, who do not share that view. Curiously, the contributions to Challenging the Dichotomy hardly mention this. Although the contributions to a collective work are necessarily limited in length, this choice may be depriving potential readers of Challenging the Dichotomy of a different view, which could at least be indicated through bibliographical references.

Personally, I find the work of Susan E. Ramírez (1996) and Rocío Delibes Mateo (2012) on the practice of guaquería (in these cases, more accurately, huaquería) in Peru following the conquest quite revealing. To understand the importance of this, it should be noted that this practice was rare in the precolonial Andean world. It was the Spaniards who spread it throughout the lands of the Tahuantinsuyo. The reasons were twofold: to use the gold and to eradicate idolatry. The brutality of the culture clash and the increasingly forceful imposition of the conquistadors' values are neatly summed up in the term used at the time to refer to the evangelisation campaigns, namely, the "eradication" of idolatry.

According to the research of Ramírez and Delibes Mateo, the response of the indigenous population was complex and tended to renegotiate meanings and its own universe of values, which had 
been drastically affected. This is not the place to elaborate on these issues. I would only note, as those authors do, that the semantic field surrounding the concept of guaca (or huaca) changed from the original field in Quechua and Aymara, as recorded by the first Spanish chroniclers, to one limited to treasure-seeking, which it soon became due to the aforementioned Spanish efforts. In this mediation, the active involvement of Indian chiefs and caciques was decisive. The so-called compañías de huacas (huaca companies), dedicated to the systematic looting of Peruvian huacas, would not have been possible without that involvement, which was moreover performative, i.e. not only, or merely, passive but active. The many lawsuits filed over rights of discovery and exploitation of huacas that were settled by the viceregal authorities offer data on this involvement and the evolving role of these tribal leaders. The lawsuit over the Yomayoguam huaca, in the former Chimú capital of Chan Chan, in 1558, is quite illuminating with regard to this mediation. In that case, the chief of the entire valley of Chimo, Antonio Chayguac, played a very active role.

Today, guaquería is a multifaceted activity. On the one hand, along with other illegal acts, such as drug cultivation and trafficking, it has become another form of financing guerrilla and paramilitary movements (Yates 2015). The case of the Malagana hacienda in 1992, which Field explores in this work, exemplifies this new development well. On the other, the Facebook groups of guaqueros and treasure-hunters, with their modern detection equipment, or those who sell pieces on eBay do not seem to fit the archetype drawn by the authors who address this issue in Challenging the Dichotomy. On the contrary, they exhibit the same attitudes and goals as many other kinds of European looters.

In any case, what I would like to emphasise about this historicity of guaquería is its evolving content, its progressive adaptation to the circumstances. The ancestral nature of the indigenous values with which the practice seems to be endowed today is the product of the native people's symbolic negotiation at each moment in the past. This means that guaquería has never been immutable and that, therefore, today it can (and perhaps should) change, too, if we expand the field of vision the activity entails in the contemporary world. Obviously, this change cannot be effected from outside 
the negotiation process with the indigenous actors themselves. However, recognising their legitimacy does not necessarily mean, as these contributions maintain, that we must ignore or trivialise legality and illegality in the rule of law.

Here a subtle question comes into play that has gone unremarked by the authors who deal with the issue of legitimacy. Is establishing the source of legitimacy just as important as understanding the difference between legitimacy and legality? In Challenging the Dichotomy, the source of legitimacy seems to be membership in a different culture, which reproduces the dynamic of autonomous "language games". As explained above, that dynamic strips everyone of the possibility of looking for points of agreement and convergence. In contemporary societies, legitimacy can no longer be ex tunc et erga omnes; it must be the product of explicit or implicit pacts. Although there is clearly a need for a new legal and political scenario able to accommodate indigenous demands, it cannot be achieved without that process of convergence around clear principles.

This brings us to the third aspect of the influence of postmodern thought on Challenging the Dichotomy: anti-modernity expressed as a confrontation with the government bodies responsible for the stewardship of archaeological heritage or with the academic discipline of archaeology itself.

Without a doubt, if there is a common enemy of indigenous legitimacy in many of the contributions to Challenging the Dichotomy it is the various government agencies responsible for protecting archaeological heritage. Clearly the actions of the ICANH, or similar institutions in other countries, are not always guided by sensitivity to or empathy with the interests of the native populations. It is worth recalling that the US government initially came out against the recognition of indigenous rights established in the UN Declaration on the Rights of Indigenous People, adopted by the UN General Assembly in 2007, although it later modified its opposition to the agreement (Den Ouden and O'Brien 2013).

It is not my aim to discredit the versions of the specific cases presented by the authors of Challenging the Dichotomy. However, judging from other information, some of their 
approaches do seem to be somewhat biased or, at least, subject to other interpretations.

Antoniadou, Mortensen and Haber question the formative process of the legal systems governing archaeological heritage in their respective countries. In this regard I partially agree with the criticism these authors make: the instruments and mechanisms of all legal systems, in particular those concerning this matter, could be improved and refined. This area of the law has moreover proven reluctant to expand participatory processes and embrace comanagement techniques with civil society. At best, such processes materialise individually in specific instruments, but that is always the exception; the rule is to reinforce hierarchy and verticality in decision-making.

However, it is questionable whether the entire regulatory process has really been so eminently damaging. In my view, the authors are using a somewhat tendentious Foucauldian "archaeology of knowledge" to explain the current situation. What I find tendentious is the biased analysis of the consequences of the link between archaeology and law to protect archaeological artefacts.

The case of Greece is striking. Antoniadou looks for the origin of the self-proclaimed right of official archaeology, the right that swept away local scholars after the birth of the modern Greek state and imposed collective symbols of an obvious nationalist bent. Here, it is sufficient to note the anachronism involved in judging past actions from a contemporary point of view, whilst ignoring factors from the historical context under study.

Following its independence from the Ottoman Empire, the only way the young Greek state could be organised was through the nationalist movement, with all the benefits and drawbacks that entailed. At the turn of the $19^{\text {th }}$ century, anything else would have been unthinkable. Antoniadou seems to neglect certain facts that would lead to very different assessments from those she sustains with regard to the formative process of Hellenic law.

Briefly, in the wake of its independence, Greece faced a need to put a firm end to the "marble fever" of the European powers (Hoock 
2007). It thus took measures to impede antiquities trafficking. The 1834 law addressed this issue from two complementary perspectives. First, it broadened the concept of historical and artistic heritage used by the law. Second, it set restrictions on the right of ownership with regard to antiquities. Article 61 of that law provided that all ancient objects were manifestations of Greece's past and, therefore, belonged to all Greeks. No ancient object could be exported without authorisation. As for the right of ownership in the case of accidental finds, half the value of the find belonged to the person who owned the property and the other half to the state. The legislative framework became stricter in the late $19^{\text {th }}$ century (Moschopoulos 2008; Voudouri 2010). Whilst the effectiveness of these measures and their implementation in practice no doubt left much to be desired, the Greek case was no different from that of the rest of its neighbours. On the contrary, as I have noted elsewhere (Rodríguez Temiño 2015), the $19^{\text {th }}$-century Greek law was the bête noire of the politically conservative Spanish regime at the time, which considered it radical.

Without again appealing to magic realism, it is worth asking whether this whole long struggle against private property for the sake of the common interest can be questioned on the strength of an anecdote. Antoniadou, for instance, offers an account of a farmer's wife who destroyed a sculpture her husband had accidentally found for fear of the consequences. For this author, the act proves the existence of other forms of excavation, with their social complexities, their various economic implications, and their own moral codes.

I do not deny it, but in reading this statement, I cannot help but wonder whether all moral codes are equally ethical. Morals govern the behaviour of people in a particular society. They are based on the traditions and values of a given context; that is why morality is a descriptive discipline. In contrast, ethics systematises the concepts of good and evil from a rational point of view, transcending the idiosyncrasies of each society. Ethics has a normative value, whereas morals are of a personal nature. The question is whether there is an authority transcendent to the moral codes themselves, the purpose of which would be to mitigate the social damage. As we have already seen, in Lyotardian "language games" there is 
not. However, in my view, this transcendent authority, which will be examined below, should exist.

Antoniadou and Mortensen question the utility of government techniques such as making public the ownership of archaeological artefacts or rewarding the handing over of accidental finds. That is not an easy question to answer. I can only note that Spanish jurists take a favourable view of the provision of the 1985 Law on Spanish Historical Heritage that considers all archaeological artefacts appearing subsequent to that date to be public property (Barcelona Llop 2000). Its contribution to the fight against archaeological looting is indisputable (Morales Bravo de Laguna 2015, Yáñez Vega 2016). Logically, it entails a clearly progressive regulatory commitment. For Antoniadou, the concept of a cash reward for reporting accidental archaeological finds evokes ambiguous messages in term of the antiquities' connection to capital and commercialisation. I can thus only imagine what she might think of the measures adopted under the 1996 English Treasure Act or the practice of the Portable Antiquities Scheme led by the British Museum (Bland 2004).

In Londoño's account of a case that reverberated beyond the Colombian borders, the anti-institutional tone is clear. He describes the 2013 controversy sparked by the desire to fly certain sculptures from the San Agustín Archaeological Park, located in the southern regions of the department of Huila, to the Colombian National Museum in Bogotá. There, they were to be featured in an exhibition called "The Return of the Idols" intended to pay homage to studies on Ullumbe culture.

Most of the data are drawn from articles and accounts published in the magazine Arcadia (Revista Arcadia 2013). According to these accounts, the local community opposed allowing the sculptures to be sent to Bogotá for three main reasons. First, the local community had not been consulted in the planning of the exhibition. Second, they feared that the sculptures would not be returned. Finally, third, the sculptures were part of a cultural landscape, so their removal and transfer, even if temporary, would alter the balance of energies at the site. Londoño uses these arguments to bolster his thesis regarding the quasi-dictatorial centralism governing the administrative work of the ICANH, which disregards any local reality not included in the legitimacy born of the link between archaeology and law. For 
Londoño, the violent attitudes that ultimately prevented the statues' removal did not take away from the legitimacy of the claims of the Yanaconas, the indigenous community that led the protests.

Little does it matters that the ICANH, which was responsible for the exhibition and the transport of the pieces, noted that the sculptures had been taken to exhibitions and returned on prior occasions without incident. Nor does it seem to matter that, in fact, the Yanacona Indians had only been in San Agustín for twenty years and, therefore, could hardly claim to be descendants of the sculptures' makers. It is similarly of little import that most of the pieces selected for the exhibition came from the collection of the local Luis Luque Gómez Museum and thus had no bearing on the site's balance of energies.

Other academics also intervened in this debate, to reproach, as interested parties do, the relative lack of work conducted at the site to explain and incorporate local points of view on the sculptures' transfer. This would seem to reinforce Londoño's idea regarding the conflict of legitimacies.

However, a Huila journalist, unrelated to the parties to the conflict and seemingly knowledgeable about the controversy, has also published an account of the events, to supplement that provided by Arcadia. According to these new data - which Londoño omits - the reason for the Yanaconas' discontent was not the sculptures. Rather, the protest masked political demands, including that unkept promises made to the group in the past be honoured. The social unrest had been promoted by certain individuals, halfhidden behind the name of an association (Comité pro Defensa del Patrimonio Ancestral or the Committee for the Defence of Ancestral Heritage), and had only mobilised a group of 80 or 100 people, out of a population of close to 40,000 . Furthermore, the association used populist assertions to achieve this mobilisation, claiming that the ICANH had already sold the pieces and would return replicas in their stead or that the exhibition was solely for the enjoyment of oligarchic rolos (a derogatory term for people from Bogotá). Some of the self-proclaimed guardians of the Agustinian heritage were known guaqueros in their own right, who had no problem selling looted archaeological objects to collectors, but who, in this belligerent situation, emerged as defenders of local heritage. 
Again, it is not my intention to make value judgments about who was right in this case. I am simply trying to show how reducing the conflict to a mere confrontation of legitimacies distorts a much more complex reality in which it is not at all easy to assign simplistic roles. Nor do I agree with the decision to elevate the poor functioning of an institution to the level of category when it is an ontologically contingent question. Undoubtedly, in this case (and possibly many others) public bodies could (or should) have done better and been more empathetic towards the local population. However, that should not be taken as something immutable, that is, as these bodies' intrinsic way of doing things. Institutions change and improve their procedures. To deny that is indicative of the marked anti-institutionalism of Londoño's position.

Field's anti-archaeology stance should also be addressed. For him, the association between archaeology and nationalism is responsible for looting, insofar as it reifies its preferred object of attention, which, in the case of Colombia, is gold. Guaquería would be the result of the transformation of the symbolic value of gold, in precolonial times, into a material value as a result, first, of Hispanic greed and, later, of the academic interest in these objects.

Field discusses the evolution of guaquería over the course of the $20^{\text {th }}$ century and its role in economically supporting political movements such as guerrillas or paramilitary groups. The Malagana hacienda disaster exemplified this new trend. There, thousands of people from all walks of life who had never before engaged in guaquería came together, intent on digging for gold objects. It was not long before the brutal violence exerted at the site by those who also controlled other forms of trafficking and criminal violence came to light. There was little the government could do in that context, beyond thwarted attempts to undertake digs and open new branches of the Gold Museum.

Despite this complexity, for Fields, archaeology has served to "whitewash" the illicit origin of many of the gold objects retrieved through guaquería once they enter the Gold Museum, a symbol of prestige and national pride. Archaeology has come to play this role by helping to expunge the symbolic value the gold once had for the natives. 
Finally, he supports that thesis by contrasting these events with what happened with wampum in the US. Objects made from these shells have also ended up in museums. However, unlike gold, he explains, they are considered historical rather than archaeological objects. Consequently, no guaquería of wampum ever substantively developed, whether as a plunder of the past or a commodification.

Personally, I think such Foucauldian genealogies of the evolution of the enunciative function and conceptual framework of mechanisms of control and power require more precise investigations. They call for a thick description that the introduction of Marxist concepts here fails to replace. Again, this is not the place for a more detailed discussion of the reifying nature of archaeology. Suffice it to say that this view does not accord with the reality of how the discipline is currently practiced.

The comparison between gold and wampum strikes me as inapt. Unlike wampum, gold already had a long history as a commercial item, which was part of the scenario of the conquest. If the comparison is made instead with American bison skins, for example, which, regardless of how the tribes used the North American plains, could be integrated into the new market established by the settlers, the results of the comparison would be more similar. By the late $19^{\text {th }}$ century, the American bison had been driven practically to extinction. As Williams T. Hornaday (1889) said, the main cause of this massacre was a clash of civilisations, one of which was not only more technologically advanced than the other, but also greedier.

In any case, the anti-institutionalism of some of the authors of Challenging the Dichotomy contrasts with the defence made by others, although this defence is not presented as such in the editors' introduction. Hollowell's chapter on the fate of objects made from walrus ivory by the Eskimos on either shore of the Bering Strait clearly comes down in favour of the Russian side. There, professional excavations have been conducted to discover the best sites to date the cultural sequence of the region's millennia-long occupation. This stands in contrast to the sporadic archaeological activity carried out on St. Lawrence Island and at other Alaskan enclaves, largely replaced with a commercial incentive for indigenous peoples to loot their past. In a deregulated environment 
with no intervention by the public authorities and a long tradition of commercial incentives to sell such objects to museums and private collectors, the establishment of a local Eskimo council was not enough to mitigate this disastrous situation. The Council granted permits to professional archaeologists and those seeking objects to sell on the black market alike.

Hollowell also introduces another element, which is missing from the book's other chapters: the consequences of this approach. When the first exhibition on Eskimo art was held in 1986, 70\% of the pieces came from the illicit trade and were decontextualised. The result of this "cultural cannibalism" is a loss of knowledge about the culture's history which may not currently seem to matter to the Eskimos, but which they may, perhaps sooner than later, come to regret.

I agree with the doubts Hollowell raises regarding the effectiveness of strictly academic means of combating the plague of unconscious looting and illicit trade. Mere exhibitions are not enough. First, they do not reach the Eskimos, who are the parties directly affected, and whilst they may impact public opinion in the artefacts' host countries, the effect is fleeting. Second, these exhibitions tend to have the perverse effect of driving up the price of the featured pieces by making them fashionable.

Both Bshara and Tapsell advocate turning the recognition of singularities, of native legitimacy, into a reform of the current regulatory environment. In this regard, Tapsell applauds the steps taken in this direction by New Zealand with respect to Maori culture. Even Gnecco and Piñacué, in their account of the complex relations between the Nasa Indians and the government authorities in Tierradentro Archaeological Park, point to the consensuses reached to include the indigenous Life Plans in the park's management plans as an ideal scenario. Although this defence does not give rise to a defence of the ICANH itself, there is an explicit assessment of the planning instruments-one of the greatest achievements of the state institutions. 
As I explained at the start of this commentary, I was struck by the fact that many of the contributions to Challenging the Dichotomy seem to settle for exalting the right to difference, to one's own legitimacy, without exploring what this confrontation between legitimacies leads to, let alone examining the link between legitimacy and legality. This aspect requires a brief, prior analysis. Certainly in the West, legitimacy and legality are associated with each other but the two concepts differ (Bobbio 1985). Legitimacy has pre-legal foundations. Not only must it be justified, as some of the chapters in Challenging the Dichotomy claim; it must also be based on consensus and built on the common interest as recognised by all members of a society. In multi-ethnic contexts, the broader this consensus is, the greater the legitimacy of the representative bodies and the laws emanating from them. The principle of legality is related to de facto power and is based on the legal system. In this context, it is hard for me to conceive of a legitimacy to destroy the common heritage of the past, potentially usurping the will of generations to come.

Tradition or cultural identity is not always a source of indisputable legitimacy for all cultural practices. The reaffirmation of some customs or traditions clashes with other social values. The prohibition in French public schools since 2004 of the hijab and other garments that meet the requirements of the Shari'ah for female attire bears witness to the existence of certain principles (equal human rights) at the very heart of the debate that make it more than a mere struggle between legitimacies. This is despite the fact that, as Laborde (2008) critically shows, republican principles must also evolve to address cultural fragmentation and the ethos of contemporary liberalism more empathetically and efficiently.

I recognise the right of indigenous peoples to defend their own legitimacy. However, it worries me when it is done in a way that adversely affects archaeological heritage, when the chronological tie to ancestors is intertwined with the basest forms of looting, aimed at meeting the collection needs of public and private institutions. Ultimately, that means depriving all people, native and non-native alike, of the right to culture.

This right is not satisfied with the mere ownership of objects, nor is it resolved by determining who has greater legitimacy to 
access archaeological artefacts, as proposed by ideological neoconservatism. It is an inherent universal right in all human beings to enrich their own personality, their ability to think about the present critically through the verified study of what happened in the past. As some of the chapters in Challenging the Dichotomy suggest, in many indigenous environments there may not currently be an awareness of the usefulness of these artefacts beyond their commercial exploitation. However, one wonders whether their grandchildren will see things the same way. The rational management of archaeological heritage begins with its conception as a non-renewable legacy that we have the obligation to transmit to future generations. That principle is not at issue in critical studies on cultural heritage. Actions of stewardship, which the editors undervalue in their introduction to the book, should be aimed precisely at guaranteeing the preservation of both the resource and its social function, which is not merely to serve as a tourist attraction-a place where postmodern thought comfortably situates it (Rodríguez Temiño 1998).

In this regard, I detected a certain resistance in the authors who addressed the issue of guacas in Challenging the Dichotomy, related to the methodological preference granted to ethnology. This view is explicitly stated multiple times throughout the book, but it is also noticeable in other devices, such as the use of autoglotonyms to refer to indigenous languages. This, of course, is in no way reprehensible, and I mention it only as an example of the aforementioned identitary bias of some of the contributions.

These contributions place guaquería in the set of cultural traits making up the identity of the native peoples who inhabit the lands of what was once Tahuantinsuyo. This is a sort of essentialist nativism resistant to change on which anthropologists have the final word (Liebmann 2008). It is an archaeologising ethnology managed with simplistic concepts of what does and does not fit in the ideal phenotype of the native, wholly immunised to reality.

I do not mean to trivialise identity issues, but rather simply to warn that their fossilisation, by researchers, gives rise to idealised types that have little to do with reality. Allow me to digress briefly to explain this point. 
Without going into any more detail than is needed, I believe there will be a certain consensus that one hallmark of traditional culture has been the search for remedies for health issues. However, when people who were brought up on home remedies and the mediation of healers to deal with illness and physical discomfort move to other social environments, they only turn to these remedies in extreme cases, when medicine offers no solution. Even elderly people who are used to such traditional means do not use them instead of medicine when they move to places with better healthcare services, but rather only to supplement it (Keefe 1981; Sánchez Mayer 1989). People change in accordance with their circumstances.

The case of the so-called "struggle for recognition" of the Indian nations in the US offers another example worth considering. On the one hand, they call for a sovereignty that was violently taken from them; however, in practice they admit that independence from the US is unthinkable (Deloria 1969). Therefore, they focus on the recognition of their cultural singularity. This is no mean feat as it involves a highly unfair procedure for the Indian nations, since it is the descendants of Europeans who must judge whether or not certain ethnic groups are pure natives. This has given rise to a struggle for this process to accept that Indian nations today need not be a faithful replica of what they were in the $19^{\text {th }}$ century: there have been substantial changes that do not detract from their nativism (Den Ouden and O'Brien 2013). The Indian nations are seeking their place in contemporary society, facing new challenges to continue existing as living groups. The controversies arising from the introduction of casinos on land administered by federally recognised Indian nations and a special tax agreement with the US government show that this adaptation faces opposition from those who continue to think that it will lead to the loss of essential and genuine aspects of Indian culture (Porter 2002, Cattelino 2010).

The theory of communicative action (Habermas 1987) offers a rational alternative to nihilism as the sole possible outcome of postmodern thought. Habermas put into play a new theory that allows for rational communication in the service of conflict resolution. The communicative action he theorised takes the form of an intersubjective dialogue to reach agreements with a 
normative content: guidelines and moral rules on which to base social coexistence. He defines it as the interaction of at least two subjects capable of language and action who establish an interpersonal relationship. Communicative action is guided by binding intersubjective rules, i.e. rules that are understood and accepted by the subjects of the action. In his view, dialogue should be guided by rational principles aimed at mutual understanding. It is not enough to recognise the legitimacy of the subjects to engage in it; communicative reason is immanent to the use of language when the aim is to achieve mutual understanding.

However, there can be no consensus without the will to achieve it. If the defence strategy is to relativise everything so as not to give value to anything at all, we will find ourselves dealing with parasitic actions that hinder the will to engage in dialogue.

Rational dialogue on agreed bases would be the optimal way to bridge the gap between the two groups, i.e. archaeologists and guaqueros. A certain analogy can be found in this case with the problem of the lack of communication between archaeologists and metal-detectorists in Europe, for which I have also proposed this path of dialogue (Rodríguez Temiño and Matas Adamuz 2012 and Rodríguez Temiño 2016).

Habermasian communicative action offers an alternative to those who champion the recognition of an innate legitimacy, inherited by birthright, to access archaeological artefacts through digs that disregard both proper recording methods and the social purpose of those artefacts. Specifically, it offers a formal principle, a procedure to control and validate which norms deserve to be universalised and accepted as legitimate. It also serves as a critical authority; any social norm that cannot be generalised or is guided by non-generalisable interests cannot be considered legitimate. This approach breaks the stagnation of the Lyotardian "language games" and their exclusively self-justifying function. Moreover, as we have seen, the path of negotiation and consensus is more productive in reality than pure confrontational protest. Logically, the will to dialogue must be mutual, and both parties must be recognised as valid interlocutors. Some of the examples cited in Challenging the Dichotomy stem from a lack of recognition of the other party and its rights, or even outright denial of its existence 
as such. In my view, that is where we must investigate further. Obviously, in the case of the Israeli-occupied territories in the West Bank, the issue is much more complex, and the situation remains far from ideal for starting a reasonable dialogue.

However, recognising the need for dialogue is not enough; first the bases for it must be laid. As I have noted elsewhere, the key lies in determining where the common interest of these artefacts lies. It seems difficult to refute that it may lie beyond the benefit it represents for the group in its broadest sense. When indigenous communities are involved, determining what should be understood by common interest requires a special approach to accommodate both the recognition of traditional forms of relationship with the past and their aggiornamento to the current situation and the preservation of this cultural legacy, amongst other things.

For very obvious reasons, I am not the right person to determine where the foundations for this dialogue should be laid. Based on what I have read about archaeological looting and the illicit sale of artefacts abroad (Boone 1993; Agurcia 1998; Gilgan 2001; Luke and Henderson 2006; Levine and Martínez de Luna 2013; Tantaleán 2013; etc.) or the comments found in metaldetecting forums (given the increasing use of such equipment in the search for archaeological remains), contrary to what has traditionally been assumed (Yates 2013; Sánchez Nava 2013), the guaquero and collector community is much broader and more complex than the one described by the authors who deal with the issue in Challenging the Dichotomy. Nor is it limited to natives. This is, of course, in addition to the fact that, as in many other countries, one of the main drivers of the sale of these objects is poverty (Hollowell 2006). In light of this reality, any mere regulatory prohibition that does not address the underlying problems will be ineffective. In other words, identifying these bases for a dialogue that, in any case, will always involve specific groups rather than broad communities, will not be easy.

This is where the role of experts, of intellectuals, to borrow a term from Zygmunt Bauman (1987), comes into play. In that experimental work, in which he still uses the term "postmodern", which he later abandoned in favour of the coinage "liquid modernity", Bauman analyses the role of intellectuals, the contemporary heirs 
of the République des Lettres, today. He identifies two different roles: one modern and the other postmodern. The difference is not a question of temporality, but rather depends on their ability to serve as a nexus. Although Bauman prefers the term "models of order" to the Lyotardian term "language games", their content is similar. Whereas modern intellectuals are characterised by their role as legislators, i.e. handing down or passing judgement on each model's governing norms, the postmodern attitude is to seek to serve as a connection between the various models of order, to act as an interpreter.

Curiously, it is the authors of Challenging the Dichotomy whose positions are, in my view, most influenced by postmodern currents who take on the role of the modern, i.e. in Bauman's terms, of legislators. However, encouraging dialogue between native guaqueros and archaeologists or cultural managers and contributing to the renegotiation of their role both for the common good and in relation to the heritage of the past (which also belongs to future generations), calls for the presence of interpreters, not legislators.

The relationship between academic (a.k.a. scientific) archaeological knowledge and the public is structured in communication models (Lewenstein 2003). Based on the cases presented in Challenging the Dichotomy, the model followed by the main heritage institutions in the countries explored, as in other places such as Spain, seems to be the so-called "deficit model". This model is based on the idea that the public has a large deficit of specific knowledge that must be remedied through the supply of information in the proper doses. This model reinforces the sense of a hierarchy and mistrust, if not outright disgust, on the part of the public. Needless to say, there are alternative models based on integrating the public into the very gestation of research and knowledge-transfer processes, as well as the co-management of archaeological heritage and culture. Latin American countries are home to an endless supply of innovative experiences in this area. In my view, that is the path to academic decolonisation. 
In writing this review, I set out to adhere to the old saying from the Wild West: don't shoot the piano player. I would not be surprised if many of the authors of Challenging the Dichotomy do not identify with the view or consequences I draw from what they have written. I should point out once again that the responsibility for this may lie in the lack of red lines delimiting what is said of its less desirable consequences. Continuing with the metaphor, I would say that I have focused on explaining what the music I have heard suggests to me. Obviously, I was not overly fond of some of the things it evoked. However, that has nothing to do with the music itself, but rather my tastes and ideas; anyone else would have a different view of this work. It is debate that allows us all to progress.

\section{References}

Agurcia, R. 1998. Copan Honduras: Looting in the Margarita Structure. Mexicon 10, 68.

Arouet, F.-M. [Voltaire] 1765. Histoire. In Encyclopédie, ou Dictionnaire raisonné des Sciences, des Arts et des Métiers, par una Societé des Gens de Lettres. Paris, 220-225.

Barber, M. B. 2005. Prehistoric Rockshelter Use on Virginia's Appalachian Plateaus: Settlement Patterns, Looting, and Survivability. Archaeology of Eastern North America 33.1, 31-49.

Barcelona Llop, J. 2000. El dominio público arqueológico. Revista de Administración Pública 151, 133-165.

Bauman, Z. 1987. Legislators and Interpreters. On modernity, post-modernity and intellectuals. Cambridge, Polity Press.

Bland, R. 2004. The Treasure Act and the Portable Antiquities scheme: a case study in developing public Archaeology. In N. Merriman (ed.). Public archaeology. London, Routledge, 272291.

Bobbio, N. 1985. El poder y el derecho. In N. Bobbio \& M. Bovero. Origen y fundamento del poder político. Mexico City, Grijalbo, 
Ignacio RODRÍGUEZ TEMIÑO - Review: Challenging the dichotomy - 129 19-36.

Boone, E. H. (ed.) 1993. Collecting the Pre-Columbian Past. Washington DC, Dumbarton Oaks Research Library and Collection.

Cattelino, J. 2010. The Double Bind of American Indian Need-Based Sovereignty. Cultural Anthropology 25.2, 235-263.

Cuno, J. B. 2008. Who Owns Antiquity?: Museums and the Battle over Our Ancient Heritage. Princeton (NJ), Princeton University Press.

Delibes Mateo, R. 2012. Desenterrando tesoros en el siglo XVI. Compañías de huaca y participación indígena en Trujillo del Perú. Seville, Universidad de Sevilla.

Deloria Jr., V. 1969. Custer Died for Your Sins. New York, Macmillan.

Den Ouden, Amy R. and O'Brien, Jean M. (eds.). Recognition, Sovereignty Struggles, \& Indigenous Rights in the United States. A Sourcebook. Chapel Hill (NC), The University of North Carolina Press.

English, P. 2013. Who controls the past? Internet Archaeology 33. http://dx.doi.org/10.11141/ia.33.9

Geertz, C. 1998. La description dense. Enquête 6, 57-72.

Gilgan, E. 2001. Looting and the Market for Maya Objects: A Belizean Perspective. In N. Brodie, J. Doole, and C. Renfrew (eds.). Trade in Illicit Antiquities: The Destruction of the World's Archaeological Heritage. Cambridge, McDonald Institute, 7388.

Habermas, J. 1987. Teoría de la acción comunicativa. 2 vols. Madrid, Trotta.

Hawley, J. C. 2015. Postcolonial Theory. In U. Sommer \& A. Gardner (eds.). Oxford Handbook of Archaeological Theory. Oxford, Oxford University Press. DOI: 10.1093/ oxfordhb/9780199567942.013.035

Hart, S. M., and Chilton, E. S. 2015. Digging and destruction: 
130 - Ignacio RODRÍGUEZ TEMIÑO - Review: Challenging the dichotomy

artifact collecting as meaningful social practice. International Journal of Heritage Studies 21.4, 318-335.

Hollowell, J. (2006). Moral arguments on subsistence digging. In C. Scarre and G. Scarre (eds.) The Ethics of Archaeology: Philosophical Perspectives on Archaeological Practice. Cambridge, Cambridge University Press, 69-96.

Hollowell-Zimmer, J. 2003. Digging in the Dirt - Ethics and 'Low End Looting'. In L. J. Zimmerman, K. D. Vitelli and J. HollowellZimmer (eds.). Ethical Issues in Archaeology. Walnut Creek (CA), AltaMira Press, 45-56.

Hoock, H. 2007. The British State and the Anglo-French Wars over Antiquities, 1798-1858. The Historical Journal 50.1, 49-72.

Hornaday, Williams T. 1889. The Extermination of the American Bison. Washington DC, Government Printing Office.

Keefe, S. E. 1981. Folk Medicine Among Urban Mexican Americans: Cultural Persistence, Change, and Displacement. Hispanic Journal of Behavioral Sciences 3.1, 41-58.

Laborde, C. 2008. Critical Republicanism. The Hijab Controversy and Political Philosophy. Oxford, Oxford University Press

Laclau, E. 1996. Deconstruction, Pragmatism, Hegemony. In C. Mouffe (ed.). Deconstruction and Pragmatism. London, Routledge, 49-71.

Levine, M. N., and Martínez de Luna, L. 2013. Museum salvage: A case study of Mesoamerican artifacts in museum collections and on the antiquities market. Journal of Field Archaeology 38.3, 264-276.

Lewenstein, B. V. 2003. Models of Public Communication of Science \& Technology. Retrieved on 10 January 2013 from [http:// www.somedicyt.org.mx/assets/hemerobiblioteca/articulos/ Lewenstein_Models_of_communication.pdf].

Liebmann, M. 2008. Introduction: The Intersection of Archaeology and Postcolonial Studies. In M. Liebmann, and U. Z. Rizvi (eds). Archaeology and the Postcolonial Critique. Walnut Creek (CA), Alta Mira, 1-20. 
Ignacio RODRÍGUEZ TEMIÑO - Review: Challenging the dichotomy - 131

Luke, C., and Henderson, J. S. 2006. The Plunder of the Ulúa Valley, Honduras, and a Market Analysis for Its Antiquities. In N. Brodie, M. M. Kersel, C. Luke, and K. W. Tubb (eds.). Archaeology, Cultural Heritage, and the Antiquities Trade. Gainesville, University Press of Florida, 147-172.

Lydon, J., and Rizvi, U. Z. (eds.) 2012. Handbook of Postcolonial Archaeology. Walnut Creek (CA), Left Coast Press, Inc.

Lyotard, J. F. 1989. La condición posmoderna. Madrid, Cátedra.

Mallouf, R. J. 1996. An unraveling rope: The looting of America's past. American Indian Quarterly 20.2, 197-208.

Mardones, J. M. 1990. El neo-conservadurismo de los posmodernos. In En torno a la posmodernidad. Barcelona, Anthropos, 2140.

Morales Bravo de Laguna, J. 2015. La Guardia Civil y la lucha contra el expolio arqueológico. Cuadernos de Prehistoria y Arqueología de la Universidad de Granada 25, 31-48.

Moreno-Caballud, L. 2017. Culturas de Cualquiera. Estudios sobre democratización cultural en la crisis del neoliberalismo español. Madrid, Acuarela \& A. Machado.

Moschopoulos, D. 2008. Administration de I'Héritage Culturel en Grèce : une approche historique. In S. Fisch (ed.). National Approaches to the Governance of Historical Heritage over Time. A Comparative Report. Amsterdam, IOS Press, 90-103.

Moser, S.; Glazier, D.; Phillips, J. E.; Nasser el Nemr, L.; Mousa, M. S.; Aiesh, R. N.; Richardson, S.; Conner A., and Seymour, M. (2002). Transforming Archaeology through Practice: Strategies for Collaborative Archaeology and the Community Archaeology Project at Quseir, Egypt. World Archaeology 34: 2, 220-248.

Porter, R. B. 2002. Pursuing the Path of Indigenization in the Era of Emergent International Law Governing the Rights of Indigenous Peoples. Yale Human Rights and Development Journal 5.1, 123-175. 
132 - Ignacio RODRÍGUEZ TEMIÑO - Review: Challenging the dichotomy

Proulx, B. B. 2013. Archaeological Site Looting in "Glocal" Perspective: Nature, Scope, and Frequency. American Journal of Archaeology 117.1, 111-125.

Ramírez, S. E. 1996. The World Upside Down. Cross-Cultural Contact and Conflict in Sixteenth-Century Peru. Stanford, Stanford University Press.

RevistaArcadia 2013. La polémica sobre la fallida exposición El retorno de los ídolos. Arcadia 14/11/2013.

Rodríguez Temiño, I. 1998. La tutela del patrimonio histórico de la modernidad a la posmodernidad. PH. Boletín del Instituto Andaluz del Patrimonio Histórico 23, 84-96.

Rodríguez Temiño, I. 2015. Coleccionismo y expolio arqueológico: los comienzos de una relación problemática. Cuadernos de Prehistoria y Arqueología de la Universidad de Granada 25, 211-256.

Rodríguez Temiño, I. 2016. Rational Grounds for Dialogue Between Archaeologists and Metal Detectorists in Spain. Open Archaeology 2, 150-159.

Rodríguez Temiño, I., and Matas Adamuz, F. J. 2013. Arqueólogos contra «piteros», «piteros» contra arqueólogos. In J. Almansa Sánchez (ed.). Arqueología Pública en España. Madrid, JAS Arqueología SLU, 187-217.

Sánchez Mayer, R. 1989. Use of Folk Medicine by Elderly MexicanAmerican Women. Journal of Drug Issues 19.2, 283-295.

Sánchez Nava, P. F. 2013. The looting of the past: Mexico's case. AP: Online Journal in Public Archaeology 3, 29-32.

Scarre, C. and Scarre, G. (eds.) 2006. The Ethics of Archaeology. Philosophical Perspectives on Archaeological Practice. Cambridge, Cambridge University Press.

Tantaleán, H. 2013. Detectors and Sondas: Brief comments on Huaqueo or plundering in Peru. AP: Online Journal in Public Archaeology 3, 17-20.

Thomas, S. 2016. The Future of Studying Hobbyist Metal Detecting 
Ignacio RODRÍGUEZ TEMIÑO - Review: Challenging the dichotomy - 133

in Europe: A Call for a Transnational Approach. Open Archaeology 2, 140-149.

Voudouri, D. 2010. Law and the Politics of the Past: Legal Protection of Cultural Heritage in Greece. International Journal of Cultural Property 17.3, 547-568.

Yáñez Vega, A. 2016. Illegal Detectorism and Archaeological Heritage: Criminal and Administrative Punitive Systems in Spain. Open Archaeology 2, 417-425

Yates, D. 2013. The theft of cultural property in Bolivia: the absence of metal detectors. AP: Online Journal in Public Archaeology $3,10-13$.

Yates, D. 2015. Displacement, Deforestation, and Drugs: Antiquities Trafficking and the Narcotics Support Economies in Guatemala. In Joris D. Kila and Marc Balcells (eds.). Cultural Property Crime. An Overview and Analysis of Contemporary Perspectives and Trends. Leiden, Brill, 23-38. 